\author{
Маркова Т.Д. \\ кандидат економічних наук, старший викладач \\ E-mail: markova-tanya12@mail.ru \\ Пчелянська Г.Б. \\ старший викладач \\ кафедра обліку та аудиту \\ Одеська національна академія харчових технологій \\ вул. Канатна, 112, м. Одеса, Україна, 65039 \\ E-mail: gaya@te.net.ua
}

\title{
ОСОБЛИВОСТІ ВИКОРИСТАННЯ ІНФОРМАЦІЙНИХ СИСТЕМ I ТЕХНОЛОГІЙ В СИСТЕМІ ОБЛІКУ ТА КОНТРОЛЮ
}

У статті досліджено особливості використання комп'ютерних інформаційних технологій в системі обліку та контролю в сфері підприємницької діяльності. Проаналізовано переваги та недоліки їх застосування в процесі ведення та прийняття рішень щодо управління бізнесом, враховуючи вимоги сучасного ринку конкурентоспроможності. Визначено змістовну сутність поняття «інформаційне суспільство» та обґрунтовано її вплив у життєдіяльності суб'єктів господарювання.

Ключові слова: інформаційне суспільство; інформаційні технології; комп'ютерна система; облік; контроль.

This work is licensed under a Creative Commons Attribution 4.0 International License http://creativecommons.org/licenses/by/4.0/

Постановка проблеми та їі зв'язок з важливими науковими та практичними завданнями. Сучасні інформаційні системи і технології вже не повільно впроваджуються, а є частиною життєдіяльності всіх сфер суспільства та всіх галузей економіки країни. Впродовж останнього десятиріччя інформаційні технології все більше і більше проникали в бізнес: це системи автоматизованого проектування i програми фінансового, податкового та управлінського обліку, це впровадження штрихкодування і системи планування виробництва. На сьогоднішній день вже й не знайдеш підприємство, яке не використало б сучасні технології хоча б для ведення бухгалтерського обліку. Неможливо уявити діяльність суб'єкта господарювання без розрахункового рахунку в банку, без програми «клієнт-банк», без електронної почти, комп'ютерної системи та пакету бухгалтерських облікових програм, служб національної безпеки - без суперкомп'ютерів, а населення - без ноутбуку, кишенькових комп'ютерів та смартфонів. Тому питання використання сучасних інформаційних систем і технологій, їх переваги та недоліки залишаються актуальними як в дослідженнях методів поліпшення та ефективності умов праці на підприємстві так і в сфеpax освітніх послуг та повсякденному житті.

Аналіз останніх публікацій 3 проблеми. Окремої розмови вимагають особливості використання сучасних інформаційних систем і технологій в обліку і контролі, що стоять перед суб'єктами господарювання, зокрема великими виробничими підприємствами. Їх немало, вони неодноразово розглядалися у працях вітчизняних та закордонних науковців. Особ- ливості інформаційних систем обліку та контролю в останні роки приділяється багато уваги у вітчизняних науково-практичних та навчальних публікаціях. Так, праці А.В. Остапенка, О.П. Колумбет, Ф.Ф. Бутинця, В.П. Завгородного, С.В. Івахненкова, Л.О. Гелей, О.В. Гриципова, О.М. Селезньової, О. Гарбич-Мошора, О.Б. Пугаченка, Я.С. Ткаль присвячені концептуальним теоретичним питанням створення і функціонування комп'ютерних інформаційних систем обліку суб'єктів господарювання. Проте, незважаючи на постійну увагу до даної проблематики, як з боку науковців так і практиків, все ще залишаються доволі суттєві прогалини, які стосуються, в першу чергу адаптації людської природи, яка має особливість впливати на майбутнє за допомогою сучасних інформаційних технологій.

Формулювання цілей дослідження. Метою статті $\epsilon$ виявлення особливостей теоретичних та практичних аспектів застосування інформаційних комп'ютерних систем в організації обліку та контролю, визначення їх переваг та недоліків.

Виклад основних результатів та їх обгрунтування. Сучасний етап розвитку цивілізації, згідно дослідженням багатьох вчених, характеризується поступовим переходом від індустріального до інформаційного суспільства. Так, інформаційне суспільство, 3 точки зору автора О. В. Грицунова, це теоретична концепція постіндустріального суспільства; історична фаза можливого розвитку цивілізації, у якій основними продуктами виробництва є інформація й знання.

Головні риси такого суспільства $є$ :

- збільшення ролі інформації та знань; 
- зростання числа людей, зайнятих інформаційними комунікаціями та виробництвом інформаційних продуктів і послуг;

- створення глобального інформаційного простору, що забезпечує ефективну інформаційну взаємодію людей, їхній доступ до світових інформаційних ресурсів і задоволення їхніх потреб в інформаційних продуктах і послугах [1].

Інформаційне суспільство - поняття філософiї історії, що характеризує якісно новий стан розвитку цивілізації, який виник завдяки мікроелектронній революції і високого рівня розвитку інформаційних технологій. Головним чинником суспільних змін стає виробництво і використання інформації, формується четвертий (поряд з сільським господарством, промисловістю, сферою послуг) інформаційний сектор економіки, а теоретичне знання стає вищою суспільною цінністю, перетворюється в символічний капітал [2].

Іовчева А. М. дійшла висновку, що інформаційне суспільство - $\epsilon$ поняттям всеохоплюючим та всезагальним. Таким, що інтегрує суспільство, консолідує владу, визначає стратегію розвитку та побудову нової соціальної формації [3].

Слід відзначити, що незважаючи на те, що модель інформаційне суспільство розглядається як орієнтир до майбутнього, вже зараз можна назвати цілий ряд викликаних інформаційною технологією змін, які підтверджують концепцію інформаційного суспільства [1]:

- структурні зміни в економіці, особливо в сфері розподілу робочої сили;

ціï;

- зросле усвідомлення важливості інформа-

- зростаюче розуміння необхідності комп'ютерної грамотності;

- широке поширення інформаційних техно-
- підтримка урядом розвитку комп'ютерної мікро- та наноелектронної технології й телекомунікацій;

- розповсюдження мережі Інтернет та забезпечення загального доступу до цієї мережі;

- зміни, пов'язані із зайнятістю населення, формування, становлення і розвиток новітніх суспільних відносин, створення нових суспільних конфігурацій, суспільних груп, суспільних відносин;

- створення нових мережних субкультур, притаманних віртуальним відносинам [4].

Сучасні інформаційні технології уможливлюють створення єдиного інформаційного середовища, фізичною основою якого $\epsilon$ інтегровані комп'ютерні мережі та системи зв'язку, що дає змогу супроводжувати та координувати і технологічні процеси, і ділову діяльність будь-якої організації. Такий підхід передбачає технічну, організаційну та методологічну інтеграцію таких базових напрямів управлінської діяльності, як виробничий, організаційний, маркетинговий, фінансовий, бухгалтерський, кадровий та проектно-конструкторський [5].

Отже, інформаційні технології і системи охоплюють весь суспільний простір та всі сфери економіки. Так, інформаційною технологією, з нашої точки зору, можна назвати систему, яка виконує функції збір інформації, іiі зберігання, оброблення та передача користувачам для прийняття рішень, прогнозування, обліку, контролю, регулювання та ін. Жодне підприємство не може обійтись без сучасних комп'ютерних інформаційних технологій для обліку, аналізу та контролю своїх господарських операцій. Проте, слід відзначити, що поряд з перевагами використання інформаційних систем і технологій на підприємствах різних галузей існують й недоліки (табл.1). логій;

Таблиця 1

Переваги та недоліки використання інформаційних систем і технологій в життєдіяльності підприсмства*

\begin{tabular}{|c|c|}
\hline Переваги & Недоліки \\
\hline $\begin{array}{l}\text { Програмний продукт автоматизації обліку можливо швидко ввести в експлуа- } \\
\text { тацію, а при зміні масштабів діяльності підприємства, підходів до управління } \\
\text { чи організації облікових робіт. }\end{array}$ & \multirow{2}{*}{$\begin{array}{l}\text { Безперервне зростання кібер- } \\
\text { злочинності (95\% фінансове } \\
\text { шахрайство та крадіжки і } 5 \% \\
\text { шпіонаж) [7]. }\end{array}$} \\
\hline Переналаштувати з мінімальними затратами часу та фінансових ресурсів. & \\
\hline Усі облікові дані реєструються та зберігають & \multirow{2}{*}{$\begin{array}{l}\text { Статичність, оновлення тех- } \\
\text { ніки, навчання персоналу, } \\
\text { висока ціна [6]. }\end{array}$} \\
\hline Швидкий доступ до інформації для прийняття управлінських рішень. & \\
\hline Широкі можливості для планування діяльності. & \multirow{2}{*}{$\begin{array}{l}\text { Залежність від всесвітньої } \\
\text { мережі Інтернет. }\end{array}$} \\
\hline Можливість постійного ведення оперативного контролю. & \\
\hline $\begin{array}{l}\text { Сучасний ергономічний інтерфейс автоматизованих програм обліку забезпечує } \\
\text { доступність засвоєння інформації та високу швидкість роботи для фахівців. }\end{array}$ & \multirow[t]{2}{*}{$\begin{array}{l}\text { Постійна необхідність адап- } \\
\text { тації до сучасних вимог часу. }\end{array}$} \\
\hline Можливість доступу до інформації через мережу & \\
\hline
\end{tabular}

* узагальнено авторами на основі $[6,7]$

Сучасні інформаційні системи і технології в бухгалтерському обліку, вважає Ткаль Я.С., поступово змінюють звичну структуру управління на підприємстві. Обчислювальна техніка суттєво підвищує якість обробки облікової інформації. Робота кваліфікованого бухгалтера стає більш спрямованою на вдосконалення організації обліку [6]. 
Розвиток сільського господарства, вважає О. П. Тітова, значною мірою, залежить від можливості і здатності керівників аграрних підприємств застосовувати більш прогресивні технології господарювання, які забезпечують ефективне використання економічного механізму відповідно до конкретних умов виробництва [8].

Бенько М.М. [9] зазначає, що здійснення фінансового аудиту в середовищі інформаційних технологій $є$ можливим і необхідним, це забезпечить: зниження трудомісткості процесів використання інформаційних ресурсів, підвищення надійності та оперативності інформаційних ресурсів, ефективну організацію діяльності людей, вирішення управлінських завдань економічного об'єкта, підвищення ефективності фінансового аудиту підвідомчих установ і закладів, вирішення управлінських завдань суб'єктів державного фінансового аудиту, підвищення ефективності окремих процесів чи комплексу процесів фінансового аудиту.

Для реалізації різноманітних цілей управління, зазнає Людвенко Д.В., використовується інформація з облікових і не облікових джерел. Однак провідна роль зберігається за обліковою інформацією. Даний пріоритет визначається тим, що бухгалтерський облік, функціонуючи і охоплюючи процеси виробництва, обігу та розподілу продукції, формує повну інформацію про кругообіг засобів. В обліку і контролі формуються інформаційні потоки зворотного зв'язку. Отже, призначення зазначених функцій полягає в організації інформації таким чином, щоб найбільш точно можна було оцінити реальний стан процесів, які регулюються у порівнянні з очікуваним і прийняти оптимальне рішення [10].

Ефективне застосування інформаційнотехнічних систем управління, що дозволяють оптимально організувати внутрішні бізнес-процеси на підприємстві і отримувати оперативну інформацію для прийняття обгрунтованих управлінських рішень $\epsilon$ автоматизація обліково-аналітичного процесу до якого прагнуть всі керівники. Вже ні у кого не викликає сумнівів, що бухгалтерський та податковий облік на сучасному підприємстві сьогодні неможливий без застосування інформаційних технологій. Ефективність управлінської діяльності залежить від багатьох чинників. Одним з головних є вміння керівника організувати роботу 3 інформаційними ресурсами. Для того щоб приймати рішення, здійснювати контроль над їх виконанням, формувати імідж підприємства, відстежувати лояльність персоналу, необхідна різноманітна інформація. Інформаційні технології використовується як при плануванні, так і при безпосередньому управлінні підрозділами або ж співробітниками безпосередньо. Інформаційними процесами досягається відразу кілька цілей: актуальність рішень; своєчасність дій; широту тактичних рішень; контроль на всіх етапах виробництва. Роль інформаційних процесів в управлінні підприємством неоціненна.

Завдяки аналізу інформаційних потоків підприємець отримує можливість аналізувати зовнішнє середовище, більш ефективно відповідати на їі ви- клики, планувати діяльність відповідно до ії ризиків, спостерігати за цільовими секторами зарубіжного ринку і багато іншого. Ефективний управлінець сьогодні - це в першу чергу новатор, який розуміє цінність інформаційних процесів.

Для управління підприємством важливо не тільки вчасно аналізувати потенційні ризики зовнішнього середовища, але також забезпечити своєчасність відповідей на такі ситуації. Якщо підприємство масштабне або ж розкидане по різним територіальним зонам, інформаційні технології - це єдина можливість забезпечити своєчасність управління. Якщо підприємець навіть й робить правильні кроки до зменшення ризиків для підприємства, якщо вони не будуть вчасно доставлені до співробітників їх цінність серйозно знижується, а іноді і повністю нівелюється.

Крім цих факторів, не можна не враховувати вплив інформаційних процесів безпосередньо на персонал, в тому числі на його найм. Для управління персоналом важлива навіть така дрібниця, як психологічний портрет співробітника, особливості його поведінки в соціальних мережах, інтереси та інше. Вплив процесів з інформатизації суспільства не можна недооцінювати, і ефективний менеджер завжди знає, що навіть подібна дрібниця може бути дуже продуктивною. Використовувати сферу інформаційні технології для управління підприємством - це вже не новаторство, а необхідність.

Важливим сектором підприємницької діяльності є виробництво. Синергія всього циклу життєдіяльності товару та інформаційних процесів життєво необхідна підприємству. Найчастіше, виробничий цикл - це послідовна зміна діяльності різних елементів системи, які спираються на досвід попередніх. Такий тип виробництва один з найбільш ефективних, проте в той же час пред'являє чималі вимоги до організації діяльності та взаємозв'язку складових.

Втрата результатів діяльності навіть одного елемента або відсутність контролю за коректністю дій на вході в систему може привести до реальних фінансових втрат. Виробництво - це в першу чергу тісний взаємозв'язок окремих складових системи, особливості управління якої полягають в необхідності як локального моніторингу, так і стратегічного напрямку. Без відповідного рівня поширення інформаційних процесів зробити це неможливо. Проте, з іншого боку, інтеграція інформаційних процесів безпосередньо у виробництво дає можливість підвищити якість продукції, що виготовляється, зменшити рівень браку, підвищити автоматизацію виробництва, налагодити диверсифікацію. Інформаційні системи зараз 3 успіхом використовуються для підвищення продуктивності виробництва, зменшення витрат, пов'язаних 3 людським фактором.

Також слід врахувати і вплив інформаційної системи на збутові можливості підприємства. Сучасне економічний простір - це в першу чергу глобалізація, і для підприємця не продуктивно орієнтуватися виключно на локальний ринок, цілком можливо саме інформаційні системи - це той фактор, який дозволить підприємству впровадити світові стандарти 
і тим самим зацікавити зарубіжного покупця в своїй продукції. Для того, щоб зрозуміти наскільки ефективний бізнес, який спирається на досягнення інформаційних технологій, досить розглянути кілька найпростіших прикладів. Наприклад, інформаційні технології в готельному бізнесі надають власнику відразу кілька переваг. По-перше, бізнес отримує можливість зацікавити потенційного клієнта не тільки на локальному ринку, але і за кордоном. По-друге, впровадження інформаційних технологій підвищує якість сервісу, надійність взаємозв'язку між адміністрацією i клієнтом, показник привабливості готелю в очах прогресивних представників соціуму [11].

Другий приклад - це ресторанний бізнес. У цій сфері інформаційні технології мають особливе значення. Саме завдяки інформаційним технологіям в ресторанному бізнесі з'явилося безліч новинок у вигляді прогресивних і екстравагантних рішень в цій сфері: від ведення бухгалтерського, податкового та управлінського обліку до популяризації різних міжнародних видів кухонь.

Слід відзначити, що неможливо обійти вплив інформаційних технологій в електронному бізнесі. Інформаційні технології електронного бізнесу - це найбільш інноваційне рішення в боротьбі за споживача. Сутність електронного бізнесу - це задоволення побажання споживача без витрати свого часу та без необхідності в подоланні простору. При цьому завдання електронного бізнесу бути якомога більш адаптивним до нововведень на ринку, це необхідно для того, щоб залишатися привабливим для користувачів, які й забезпечують такому підприємству дохід. Користувач хоче як можна більш свіжу інформацію, постійно вдосконалений сервіс, двосторонній зв'язок 3 адміністрацією [11].

Отже, роль інформаційних технологій в усіх сферах малого, середнього та великого бізнесу є забезпечення ефективності роботи, автоматизації обліково-аналітичного процесу, отримання доходу, виконання функції управління та задоволення потреб користувачів.

Висновки та перспективи подальших досліджень. Інформація поступово стала потужним засобом впливу та регламентації суспільного життя. Інформаційні технології стають все більше доступними та незамінними в функціонуванні суспільноекономічних та управлінських процесів. Не достатньо мати лише комп'ютерну систему для ведення господарської діяльності, важливим елементом є програмне забезпечення, що дозволяє виконувати функції ведення даних, обробка, обліку, аналізу, контролю. Проте, слід зауважити, що часто керівники підприємств зустрічаються 3 проблемою вибору оптимального програмного забезпечення свого специфічного виду діяльності. Сьогодні ринок пропонує чималий вибір програмних продуктів ведення господарської діяльності підприємств від малого бізнесу до великих корпорацій, що й залишається питанням майбутніх досліджень

\section{Література}

1. Грицунов О. В. Інформаційні системи та технології: навч. посіб. для студентів за напрямом підготовки «Транспортні технології» / О. В. Грицунов. - Х.: ХНАМГ, 2010. - 222 с.

2. Рижко Л. В. Інформаційне суспільство: особливості наукового простору / Л. В. Рижко // Вісник Національного авіаційного університету. Сер. : Філософія. Культурологія. - 2010. - № 2. - С. 31-36.

3. Іовчева А. М. Інформаційне суспільство в умовах глобалізаційного розвитку / А. М. Іовчева // Наукові праці [Чорноморського державного університету імені Петра Могили комплексу «Києво-Могилянська академія»]. Сер. : Політологія. - 2014. - Т. 236, Вип. 224. - С. 108-111.

4. Петрухно Ю. Є. Інформаційне суспільство: поняття, основні складові, характеристика / Ю. Є. Петрухно // Вісник Одеського національного університету. Сер. : Бібліотекознавство. Бібліографознавство. Книгознавство. - 2014. - Т. 19, Вип. 1. - С. 127-133.

5. Яцюк С. Особливості методики викладання інформаційних систем і технологій для студентівменеджерів / С. Яцюк // Науковий вісник Східноєвропейського національного університету імені Лесі Українки. Педагогічні науки. - 2013. - № 7. - С. 92-95.

6. Ткаль Я. С. Особливості використання інформаційних систем і технологій обліку / Я. С. Ткаль // Вісник Бердянського університету менеджменту і бізнесу - 2014. - № 2 (26). - С.127-130.

7. Луценко В.М. Особливості системи контролю інформації потоків великого розміру // В.М. Луценко, А.М. Балан // Захист інформації. - 2013 - №3. - С.231-235.

8. Тітова О. П. Особливості та переваги використання новітніх інформаційни технологій в управлінні агрохолдингу «Укрлендфармін» / О. П. Тітова // Вісник Житомирського національного агроекологічного університету. - 2012. - № 2(2). - С. 90-96.

9. Бенько М.М. Можливості здійснення фінансового аудиту у середовищі інформаційних технологій / М. М. Бенько // Вісник Житомирського державного технологічного університету. Сер. : Економічні науки. 2013. - № 2. - С. 3-8.

10. Людвенко Д.В. Особливості функціонування обліково-інформаційних систем на сучасних підприємствах / Д. В. Людвенко // Науковий вісник Львівського національного університету ветеринарної медицини та біотехнологій ім. Гжицького. - 2011. - Т. 13, № 1(2). - С. 42-46. 
11. Информатизация предприятия: преимущества и недостатки [Електронний ресурс]. - Режим доступу : http://economyz.ru/informatsionnye-tekhnologii-v-biznese/

Стаття надійшла 5.08.2016

Стаття прийнята до друку 19.08.2016

Доступно в мережі Internet 30.09.2016

\author{
Маркова Т.Д. \\ кандидат экономических наук, старший преподаватель \\ E-mail: markova-tanya12@mail.ru \\ Пчелянская Г.Б. \\ старший преподаватель \\ кафедра учета и аудита \\ Одесская национальная академия пищевых технологий \\ ул. Канатная, 112, г. Одеса, Украина, 65039 \\ E-mail: gaya@te.net.ua
}

\title{
ОСОБЕННОСТИ ИСПОЛЬЗОВАНИЯ ИНФОРМАЦИОННЫХ СИСТЕМ И ТЕХНОЛОГИЙ В СИСТЕМЕ УЧЕТА И КОНТРОЛЯ
}

В статье исследованы особенности использования компьютерных информационных технологий в системе учета и контроля в сорере предпринимательской деятельности. Следует отметить, что современные информационные системы и технологии являются частью жизнедеятельности всех сфер общества и всех отраслей экономики страны. Внедрение информационных технологий, не вооруженным глазом, можно наблюдать в сфере бизнеса: это системы автоматизированного проектирования и программы финансового, налогового и управленческого учета, это внедрение штрихкодирования и системы планирования производства.

Проанализированы преимущества и недостатки их применения в процессе ведения и принятия решений по управлению бизнесом, с учитом требования современного рынка конкурентоспособности. Однако следует отметить, что наряду с преимуществами (современный эргономичный интерфейс автоматизированных программ учета обеспечивает доступность усвоения информации и высокую скорость работы для специалистов) использования информационных систем и технологий на предприятиях различных отраслей существуют и недостатки (непрерывный рост киберпреступности).

Таким образом, информационные технологии и системы охватывают все общественное пространство и все сферы экономики. Роль информационных технологий во всех сферах малого, среднего и крупного бизнеса является обеспечение эфффективности работы, автоматизации учетноаналитического процесса, получения дохода, выполнение функции управления и удовлетворения потребностей пользователей.

Ключевые слова: информационное общество; информационные технологии; компьютерная система; учет; контроль.

\author{
Markova T. \\ Ph.D. in Economics, Assistant \\ E-mail: markova-tanya12@mail.ru \\ Pchelianska G. \\ Assistant \\ Department of Accounting and Auditing \\ Odessa National Academy of Food Technologies \\ Kanatna str., 112, Odessa, Ukraine, 65039 \\ E-mail: gaya@te.net.ua
}

\section{FEATURES OF USE OF INFORMATION SYSTEMS AND TECHNOLOGIES IN SYSTEM OF THE ACCOUNT AND CONTROL}

In article features of use of computer information technologies in system of accounting and control in the sphere of business activity are researched. It should be noted that modern information systems and 
technologies are a part of activity of all spheres of society and all industries of national economy. Implementation of information technologies, not to an aided eye, it is possible to observe in the sphere of business: these are systems of the automated designing and the program of financial, tax and managerial accounting, this implementation of a shtrikhkodiro-vaniye and planning system of production.

Benefits and shortcomings of their application in the course of maintaining and decision making on business management, with accounting of the requirement of the modern market of competitiveness are analysed. However it should be noted that along with benefits (the modern ergonomic interface of the automated programs of accounting provides availability of assimilation of information and high speed of work to specialists) uses of information systems and technologies at the entities of various industries there are also shortcomings (continuous growth of cybercrime).

Thus, information technologies and systems cover all public space and all spheres of economy. The role of information technologies in all spheres of small, average and large business is ensuring overall performance, automation of accounting and analytical process, income acquisition, accomplishment of management function and satisfaction of needs of users.

Keywords: information society; information technologies; computer system; accounting; control.

\section{References}

1. Hrytsunov, O. V. (2010). Informatsiini systemy ta tekhnolohii. Kh.: KhNAMH.

2. Ryzhko, L. V. (2010). Informatsiine suspilstvo: Osoblyvosti naukovoho prostoru. Visnyk Natsionalnoho Aviatsiinoho UniversytetuSer. : Filosofiia. Kulturolohiia., 2, 31-36.

3. Iovcheva, A. M. (2014). Informatsiine suspilstvo v umovakh hlobalizatsiinoho rozvytku. Naukovi Pratsi.Chornomorskoho Derzhavnoho Universytetu Imeni Petra Mohyly Kompleksu «Kyievo-Mohylianska Akademiia».Ser. : Politolohiia, 236(224), 108-111.

4. Petrukhno, I. I. (2014). Informatsiine suspilstvo: Poniattia, osnovni skladovi, kharakterystyka. Visnyk Odeskoho Natsionalnoho Universytetu. Ser. : Bibliotekoznavstvo.Bibliohrafoznavstvo. Knyhoznavstvo., 19(1), 127133.

5. Iatsiuk, S. (2013). Osoblyvosti metodyky vykladannia informatsiinykh system i tekhnolohii dlia studentivmenedzheriv. Naukovyi Visnyk Skhidnoievropeiskoho Natsionalnoho Universytetu Imeni Lesi Ukrainky. Pedahohichni Nauky, 7, 91-95.

6. Tkal, I. S. (2014). Osoblyvosti vykorystannia informatsiinykh system i tekhnolohii obliku. Visnyk Berdianskoho Universytetu Menedzhmentu I Biznesu, 2(26), 127-130.

7. Lutsenko, V. M., \& Balan, A. M. (2013). Osoblyvosti systemy kontroliu informatsii potokiv velykoho rozmiru. Zakhyst Informatsii, 3, 321-235.

8. Titova, O. P. (2012). Osoblyvosti ta perevahy vykorystannia novitnikh informatsiiny tekhnolohii v upravlinni ahrokholdynhu «Ukrlendfarmin». Visnyk Zhytomyrskoho Natsionalnoho Ahroekolohichnoho Universytetu, 2(2), 90-96.

9. Benko, M. M. (2013). Mozhlyvosti zdiisnennia finansovoho audytu u seredovyshchi informatsiinykh tekhnolohii. Visnyk Zhytomyrskoho Derzhavnoho Tekhnolohichnoho Universytetu. Ser. : Ekonomichni Nauky, 2, 3-8.

10. Liudvenko, D. V. (2011). Osoblyvosti funktsionuvannia oblikovo-informatsiinykh system na suchasnykh pidpryiemstvakh. Naukovyi Visnyk Lvivskoho Natsionalnoho Universytetu Veterynarnoi Medytsyny Ta Biotekhnolohii Im. Gzhytskoho, 1(2), 13th ser., 42-46.

11. Ynformatyzatsyia predpryiatyia: Preymushchestva y nedostatky. (2016). Retrieved 2016, from http://economyz.ru/informatsionnye-tekhnologii-v-biznese/ 